International Journal of Social Science And Human Research

ISSN(print): 2644-0679, ISSN(online): 2644-0695

Volume 05 Issue 01 January 2022

DOI: 10.47191/ijsshr/v5-i1-14, Impact factor-5.586

Page No: $84-87$

\title{
Web-Based Teaching Materials in the Covid-19 Pandemic: Implementation of Technological Advancements
}

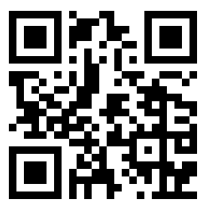

\author{
Fiona Alde Risa ${ }^{1}$, Novi Anoegrajekti ${ }^{2}$, Miftahulkhairah Anwar $^{3}$ \\ ${ }^{1,2,3}$ Language Education, Postgraduate, Jakarta State University
}

\begin{abstract}
This study aimed to determine web-based teaching materials in the covid-19 pandemic time as implementation of technological advancements. The method used is literature study or literature review. A literature study is a research design used in collecting data sources related to a topic. It collects data for the study of literature using a database to search for literature sources. Data collection used the Reporting Items for Systematic Review and Meta-Analysis (PRISMA) method. From the results of research and discussion, it can be concluded that the web or website is a site that contains various documents and information that can be accessed by individuals and groups using the internet. Because of its superiority in finding information, the website is widely used as a medium of communication, promoting business, and even learning activities. Through the website, the implementation of learning will be easier and more interesting. Students can access various learning resources through the website, provide complete practice questions, and provide discussion space for students and interesting visualizations.
\end{abstract}

KEYWORDS: Web-Based, Teaching, Covid-19 Pandemic

\section{INTRODUCTION}

The development of an increasingly rapid era is marked by increasingly sophisticated technological advances, where now all interactions and connections can be made virtually. With the advancement of technology, it is certainly very influential on developments in the field of education. Education in Indonesia is currently very literate with the presence of technology used, especially in the era of the covid-19 pandemic, such as the use of Google Classroom, Google Meet, LMS, WhatsApp, and Zoom applications that make it easier to carry out learning activities. These applications can be combined in learning activities, especially during a pandemic, such as the delivery of material that can be delivered by the teacher via Zoom, while for assigning assignments and collecting assignments, you can use Google Classroom. The combination of these various applications greatly facilitates the teacher in achieving the maximum learning objectives even though face-to-face. Currently, online learning and using these applications have become commonplace used by teachers and students in carrying out learning, especially asynchronously. However, the use of these applications must be balanced with the cleverness of the teacher in presenting interesting material and being able to present fun learning even online.

In addition to being able to present interesting learning, of course, as a teacher, the teacher has an obligation to develop learning that is useful in overcoming the difficulties of students and making learning effective and innovative. Therefore, it is necessary to improve in the field of education to balance the demands of an increasingly advanced era. One of them is developing teaching materials. The development of these teaching materials can later be used to overcome the difficulties experienced by students so that the resulting output can be achieved better. Therefore, it is necessary to develop teaching materials that can be used as a solution to overcome students' difficulties in learning. Furthermore, in this era of information technology, it is necessary to develop teaching materials by maximizing the use of existing technology. This is done to produce a creative, innovative, and competitive generation. One of them is web-based learning. The teaching materials that will be developed later are in the form of a web. Web-based learning later by utilizing blogs consisting of material, questions, student assignments, grades, and much more.

Another research related to the development of teaching materials, conducted by ( Himang, 2019), revealed that the development of experience-based teaching materials was valid, effective, and practical to use as teaching materials for writing short stories. In addition to research on the development of short story writing teaching materials, there are several studies on the development of web-based teaching materials. For example, the research conducted by (Budiana \& Mumpuni, 2019) revealed that the development of web-based teaching materials is appropriate for use in the learning process because there are differences before and after students use web-based teaching materials with procedural text materials. So the development of teaching 
materials effectively improves students' speaking skills. Another related research conducted by (Junita \& Sukardi, 2020) states that web-based learning modules are very practical for students to use. Students can use it both at school and outside of school.

Based on the difficulties experienced by students due to the absence of interesting teaching materials that can facilitate students in learning and can be used anywhere easily by students. One of the interesting and easy-to-use teaching materials for students is web-based teaching materials. The use of websites as teaching materials can maximize learning to write short stories, such as providing various content in text, audio, and even video. The use of technology today can be an alternative in developing teaching material. In the era of sophisticated technology and information today, learning that can implement technological advances is needed, one of which is web-based learning. The use of web-based teaching materials effectively improves students' abilities and learning outcomes (Budiana \& Mumpuni, 2019; Dermawan \& Fahmi, 2020).

\section{METHODS}

The method used is literature study or literature review. A literature study is a research design used in collecting data sources related to a topic. The literature study aims to describe the main content based on the information obtained (Herliandry et al., 2020). Data collection is carried out using a database to search for literature sources. This data collection uses the Preferred Reporting Items for Systematic Reviews and Meta-Analysis (PRISMA) method. The research was carried out by analyzing journals and then making a summary related to the study objectives. The journal search procedure has the PICOT procedure criteria. The PICOT method has been extended to the questions used to review journals. Researchers conducted a review of journals in the last ten years. The strategies used in the literature search were collected from national and international journal providers' databases. The national and international journal providers database can be accessed through several websites. The access used to search for the articles reviewed is Google Scholar, Eric, and Scopus with the search terms grassroots, advantages, and disadvantages.

\section{RESULTS AND DISCUSSION}

\section{Definition of Teaching Materials}

Teaching materials are tools needed in the learning process that contain materials, methods, limitations, and ways of evaluating. Supporting this statement, (Rahmawati, Fauziah, and Leni 2020) state that teaching materials are all forms of materials used to assist teachers and students in supporting the learning process to conform to the goals that have been set. Teaching materials consist of information, tools, and texts that are arranged systematically. The material displays the overall competencies that students will master. Teaching materials are used as a tool in the learning process to plan and study the implementation of learning.

Teaching materials are learning programs that play a very important role in the learning process. Teaching materials are prepared to provide learning materials that are by the demands of the applicable curriculum by taking into account the needs of students, which include the characteristics and environment of students. In addition, teaching materials can help students find alternative materials other than textbooks that are sometimes difficult to understand (Hardiansyah et al., 2019; Iwan et al., 2020).

(Khulsum, Hudiyono, \& Selistyowati, 2018) Revealed that teaching materials are a set of materials made by teachers that function to support learning activities, it is intended that learning activities follow the expected competencies. Supporting this statement (Himang, Mulawarman, \& Ilyas 2019) revealed that teaching materials are a set of learning tools consisting of various components such as learning materials, methods, and limitations to evaluate a lesson. In general, a teaching material must be arranged systematically and attractively for students so that the learning process can be carried out properly.

From some of the opinions above, it can be synthesized that teaching materials are tools used so that the learning process can be carried out on target. Therefore, teaching materials have various components such as learning materials, methods, and ways of evaluating. These components must be arranged systematically and attractively to present fun learning for students.

\section{Characteristics of Teaching Materials}

(Rahmawati et al., 2020) reveals that the characteristics of teaching materials are a) reflecting a modern point of view on the subject and its presentation, b) providing a regular and gradual source, c) presenting the appropriate subject matter, d) presenting various kinds of models, methods, and teaching facilities, e) presenting assignments and exercises, f) providing evaluation and remedial materials.

\section{Types of Teaching Materials}

Furthermore, (Himang, 2019) revealed various types of teaching materials in the form of books, modules, and computer-based teaching materials. In addition, non-printed teaching materials include audio, audiovisual, and interactive multimedia teaching materials.

Based on the explanation above regarding the types of teaching materials, it can be concluded that teaching materials have various types, ranging from conventional teaching materials, namely the most widely used printed materials today such as modules and books, to modern teaching materials that utilize types of media such as audio. Text, images, videos and so on. 
The development of web-based teaching materials can be an alternative that can be used to improve students' skills to write short stories, especially during the COVID-19 pandemic. In this very advanced era, students are already accustomed to surfing the internet in search of information, so the use of the web can be very helpful for students in carrying out learning because the material can be directly accessed using a device. In addition, research on web-based language learning has not been widely carried out. Compared to previous research, the novelty in this study is that the website used has several syntaxes for writing short stories, including the stages of determining the theme, collecting materials, making drafts, developing drafts, making titles, revisions, and publications. These stages can make it easier for students to develop ideas, design a clear flow, and provide opportunities for students to publish their work in the Wattpad application. In addition, the website will have various short stories references that are connected via a link to Wattpad.

The web or website is a page or collection of sites and documents spread throughout the world through server computer devices connected via the internet network (Batubara, 2018). In line with that, (Zahir, 2019) revealed that the website is a component consisting of text, images, sound, and animation to be an interesting medium of information if visited by other people. A similar opinion was expressed by Divayana (Utami et al., 2020) that a website is defined as a collection of pages that display various kinds of information, be it text, still and motion pictures, animation, sound, or a combination of all of them connected via the internet.

The web is a service that users can use if connected via the internet. Learning using the website can be a repository of information and interactive media (Anggoro \& Yunianta, 2018). Then according to (Batubara, 2018), website-based learning is one example of electronic learning (e-learning) with the implementation of learning activities assisted by internet technology. A similar opinion was expressed by (Zahir, 2019) web-based learning is a learning process carried out by education and students using the internet as a learning tool.

Web-based teaching materials can be interpreted as teaching materials that use electronic devices such as the web. Webbased teaching materials are the presentation of teaching materials using existing technology on devices/laptops using the internet network. It is used for independent learning resources with easy operations and practical use (Junita \& Sukardi, 2020).

\section{CONCLUSION}

From the results of research and discussion, it can be concluded that the web or website is a site that contains various documents and information that can be accessed by individuals and groups using the internet. Because of its superiority in finding information, the website is widely used as a medium of communication, promoting business, and even learning activities. Through the website, the implementation of learning will be easier and more interesting. Students can access various learning resources through the website, provide complete practice questions, and provide discussion space for students and interesting visualizations.

\section{REFERENCES}

1) Anggoro, I. F., \& Yunianta, T. N. H. (2018). Development of Learning Media Website-Based for Trigonometry. Pendidikan Matematika, 4(2018), 253-260.

2) Batubara, H. H. (2018). Pembelajaran Berbasis Web Dengan Moodle Versi 3.4 - Hamdan Husein Batubara - Google Books. Cv Budi Utama, halaman 2(April), 227. https://doi.org/10.13140/RG.2.2.20230.88643

3) Budiana, N., \& Mumpuni, A. (2019a). Pengembangan Materi Ajar Bahasa Indonesia Berbasis Web Dengan Teknik Pidato Untuk Meningkatkan Keterampilan Berbicara Siswa Kelas Xi Sma Negeri 1 Wanasari Brebes. Syntax Literate: Jurnal Ilmiah Indonesia, 4(11), 134-151.

4) Budiana, N., \& Mumpuni, D. A. (2019b). Pengembangan Materi Ajar Berbicara Berbasis Web untuk Meningkatkan Keterampilan Berbicara Siswa Kelas XI di SMA. Prosiding Seminar Nasional Linguistik Dan Sastra (SEMANTIKS), l(0), 2019.

5) Dermawan \& Fahmi, R. (2020). Pengembangan e-modul berbasis web pada mata pelajaran pembuatan busana industri. Jurnal Pedagogi Dan Pembelajaran, 3(3), 508-515.

6) Hardiansyah, H., Rusmono, R., \& Winarsih, M. (2019). Teaching material development of natural environment based on mobile learning on elementary school. Journal of Physics: Conference Series, 1402(7). https://doi.org/10.1088/17426596/1402/7/077075

7) Herliandry, L. D., Nurhasanah, N., Suban, M. E., \& Kuswanto, H. (2020). Pembelajaran Pada Masa Pandemi Covid-19. JTP - Jurnal Teknologi Pendidikan, 22(1), 65-70. https://doi.org/10.21009/jtp.v22i1.15286

8) Himang, V. H., Mulawarman, W. G., \& Ilyas, M. (2019). Pengembangan Bahan Ajar Menulis Cerpen Berbasis Pengalaman Siswa Kelas XI SMK. Diglosia: Jurnal Kajian Bahasa, Sastra, Dan Pengajarannya, 2(2), 93-102. https://doi.org/10.30872/diglosia.v2i2.pp93-102

9) Iwan, I., Istisaroh, I., Sirait, S. H. K., \& Damopolii, I. (2020). The development of teaching materials oriented problembased learning integrating Tifa to train student's critical thinking skills. AIP Conference Proceedings, 2215(April). https://doi.org/10.1063/5.0000587 
Web-Based Teaching Materials in the Covid-19 Pandemic: Implementation of Technological Advancements

10) Junita, I., \& Sukardi, S. (2020). Pengembangan Modul Pembelajaran Berbasis Web pada Mata Pelajaran Penerapan Rangkaian Elektronika. Jurnal Pendidikan Teknik Elektro, 01(01), 122-125.

11) Khulsum, U., Hudiyono, Y., \& Sulistyowati, E. D. (2018). Pengembangan Bahan Ajar Menulis Cerpen Dengan Media Storyboard Pada Siswa Kelas X Sma. DIGLOSIA : Jurnal Kajian Bahasa, Sastra, Dan Pengajarannya, 1(1), 1-12. https://doi.org/10.30872/diglosia.v1i1.pp1-12

12) Rahmawati, A., Fauziah, D. R., \& Leni. (2020). Menjadi Guru Profesional. Universitas Djuanda Bogor.

13) Utami, R. S., Aji, S. D., \& Chrisyarani, D. D. (2020). Pengembangan Media Pembelajaran Berbasis Website Tema 6 Subtema 1 Kelas IV. Seminar Nasional PGSD UNIKAMA, 4(20), 1-9.

14) Zahir, A. (2019). Pengembangan Media Pembelajaran Live Streaming Pengetahuan Komputer Berbasis Website. Jurnal Ilmiah d'COMPUTARE, 9(2), 1-7. 